\title{
Effect of thapsigargin on P-glycoprotein-negative and P-glycoprotein-positive L1210 mouse leukaemia cells
}

\author{
Mário Šereš ${ }^{1}$, Peter Ditte ${ }^{2}$, Albert Breier ${ }^{1}$ and Zdena Sulová ${ }^{1}$ \\ ${ }^{1}$ Institute of Molecular Physiology and Genetics, Centre of Excellence of the Slovak Research and Development Agency \\ „Biomembranes 2008”, Slovak Academy of Sciences, Bratislava, Slovakia \\ ${ }^{2}$ Institute of Virology, Slovak Academy of Sciences, Bratislava, Slovakia
}

\begin{abstract}
Expression of drug-transporting P-glycoprotein (P-gp, an integral protein of the plasma membrane) in neoplastic cells confers multidrug resistance and also involves alteration of cell sensitivity to inhibitors of the sarco/endoplasmic reticulum calcium pump thapsigargin (Th). Mouse leukaemia L1210 cell sublines that overexpress P-gp due to selection with vincristine (R) or stable transfection with a gene encoding human P-gp (T) were less sensitive to Th than the parental cell line (S). Th at a concentration of $0.1 \mu \mathrm{mol} / \mathrm{l}$ did not induce alterations in the amount of P-gp mRNA in R or T cells ( $\mathrm{S}$ cells did not contain any measurable amount of this transcript as assessed by RT-PCR) or in the amount of calnexin (CNX) or glyceraldehyde-3-phosphate dehydrogenase (GAPDH) in all three cell sublines. However, when using a concentration of $10 \mu \mathrm{mol} / \mathrm{l}$, Th decreases the amounts of CNX, GAPDH (in S, R and T cells) and P-gp (in $\mathrm{R}$ and $\mathrm{T}$ cells) mRNAs. In contrast to $\mathrm{R}$ and $\mathrm{T}$ cells (which contain abundant $\mathrm{P}$-gp), $\mathrm{S}$ cells did not contain any P-gp detectable by the c219 antibody on a Western blot. Th at a concentration of $0.1 \mu \mathrm{mol} / \mathrm{l}$ induced a reduction in the amount of $\mathrm{P}$-gp present in $\mathrm{R}$ and $\mathrm{T}$ cells, particularly in isoforms with higher molecular weights (i.e., mature fully glycosylated isoforms). Similar results were observed when $\mathrm{Th}$ was used at a concentration of $10 \mu \mathrm{mol} / \mathrm{l}$. R and T cells contained lower levels of CNX than $\mathrm{S}$ cells. While Th at a lower concentration did not alter the levels of $\mathrm{CNX}$ in $\mathrm{S}$, R or $\mathrm{T}$ cells, a higher concentration of this substance induced a measurable decrease in the amount of CNX. S, R and T cells did not differ with respect to GAPDH content, but Th induced a reduction in the amount of this protein in all cell sublines. More pronounced results were observed when Th was applied at a concentration of $10 \mu \mathrm{mol} / \mathrm{l}$ comparing with a concentration of $0.1 \mathrm{mmol} / \mathrm{l}$. These changes may be involved together with the Th efflux activity of P-gp in Th-resistance associated with the P-gp-mediated multidrug resistance of $\mathrm{R}$ and $\mathrm{T}$ cells.
\end{abstract}

Key words: L1210 cells - Multidrug resistance - P-glycoprotein - Thapsigargin - Calnexin - GAPDH

\begin{abstract}
Abbreviations: CNX, calnexin; GAPDH, glyceraldehyde-3-phosphate dehydrogenase; MDR, multidrug resistance; P-gp, P-glycoprotein; R, drug-resistant L1210 cell sublines overexpressing P-gp due to selection with vincristine; $\mathrm{S}$, drug-sensitive parental L1210 cell subline; SERCA, sarco(endo)plasmic reticulum $\mathrm{Ca}^{2+}$-ATPase; $\mathrm{T}$, drug-resistant $\mathrm{L} 1210$ cell sublines overexpressing P-gp due to transfection with human gene encoding P-gp; Th, thapsigargin.
\end{abstract}

\section{Introduction}

Multidrug resistance (MDR) of neoplastic tissue represents a real obstacle in effective chemotherapy-based treatment of

Correspondence to: Zdena Sulova, Institute of Molecular Physiology and Genetics, Slovak Academy of Sciences, Vlárska 5, 83334 Bratislava, Slovakia

E-mail: zdena.sulova@savba.sk cancer (Broxterman et al. 2009; Baguley 2010). Overexpression of the plasma membrane drug efflux pump P-glycoprotein (P-gp), the ABCB1 member of the ABC transporter family, is the most commonly observed cause of decreased cell sensitivities to multiple groups of drugs with different structures and mechanisms of cytotoxicity (Hall et al. 2009). Exposure of cells to the selection pressure of cytotoxic drugs leads to the development of drug resistance (Breier et al. 2005). Under these conditions, several changes in cell 
structure and metabolism can be observed. Alterations in the intracellular calcium homeostasis associated with P-gp overexpression were recently described (Mestdagh et al. 1994; Sulova et al. 2005, 2009; Liu et al. 2010). These alterations could be related to cellular resistance to thapsigargin (Th), an inhibitor of the sarco/endoplasmic reticulum $\mathrm{Ca}^{2+}$-ATPase (SERCA) that has been observed in P-gp-overexpressing cells (Gutheil et al. 1994; Wagner-Souza et al. 2003; O'Neill et al. 2006; Seres et al. 2008). While Th has been demonstrated to be a P-gp substrate (Gutheil et al. 1994; Rishi et al. 1998), several authors have shown that some factor other than P-gpmediated Th efflux is involved in reducing the Th sensitivity of P-gp-positive cells (Rumjanek et al. 2001; Wagner-Souza et al. 2003; Seres et al. 2008). Loo and Clarke (1994, 1995) described the role of the calcium-dependent endoplasmic reticulum chaperone calnexin (CNX), a lectin, in the quality control of newly synthesised P-gp. In mouse leukaemia L1210/VCR cells selected for P-gp-mediated MDR by vincristine (VCR) (Polekova et al. 1992), a lower level of CNX was observed compared to parental P-gp-negative L1210 cells (Seres et al. 2008). However, a measurable amount of CNXP-gp complex was found in L1210/VCR cells by immunoprecipitation with an antibody against $\mathrm{CNX}$, thus verifying the role of CNX in P-gp processing in this cell type. In the present study, we measured the effects of Th on P-gp and CNX protein and mRNA levels in L1210 cells, L1210/VCR cells and L1210/T cells (in which overexpression of P-gp was induced by stable transfection with the gene encoding human P-gp) (Sulova et al. 2010). For measurements, two Th concentrations inducing low $(0.1 \mu \mathrm{mol} / \mathrm{l})$ and high (10 $\mu \mathrm{mol} / \mathrm{l})$ levels of cell death were chosen for all three sublines of L1210 cells.

\section{Materials and Methods}

\section{Cells and cultivation conditions}

P-gp-overexpressing cells were obtained from mouse leukaemia L1210 cells (S) by stepwise adaptation to vincristine (R) (Polekova et al. 1992) or by stable transfection with the Addgene plasmid 10957 (pHaMDRwt), a retrovirus carrying the full-length P-gp cDNA (Pastan et al. 1988), to produce T cells, which express a level of P-gp similar to that found in $\mathrm{R}$ cells (Sulova et al. 2010). Cells were cultured for two days in a humidified atmosphere supplemented with $5 \% \mathrm{CO}_{2}$ at $37^{\circ} \mathrm{C}$ in standard RPMI medium containing glutamine $(1 \mathrm{mg} / \mathrm{ml}), 4 \%$ bovine foetal serum and $20 \mathrm{mg} / \mathrm{l}$ gentamicin (Invitrogen, USA).

Cells $\left(1 \times 10^{7}\right)$ were incubated for 8 hours in $5 \mathrm{ml}$ of cultivation medium containing $0,0.1$ or $10 \mu \mathrm{mol} / 1$ Th under the same conditions as described for cell cultivation. After incubation, cells were spun down and used for further measurements.

\section{Measurement of thapsigargin cell death effect}

After incubation with Th, the cell suspensions were adjusted to $1 \times 10^{6}$ cells per $\mathrm{ml}$ PBS containing propidium iodide (final concentration $0.6 \mu \mathrm{g} / \mathrm{ml}$ ) and were analysed by flow cytometry using a Coulter Altra flow cytometer (Beckman Coulter, USA).

\section{Detection of mRNA encoding P-gp and CNX}

Total cellular mRNA was extracted from S, R and T cells using the RNA-solvent reagent concentrate R6830-02IN (Omega Bio-Tek, USA). mRNA was reverse-transcribed to cDNA using a First Strand cDNA Synthesis Kit (Novagen, USA). mRNA extraction and cDNA synthesis were carried out according to the protocols recommended by Novagen. PCR reactions included Nova Taq PCR Master Mix (Novagen USA). The following PCR primers were used: 5'-CCC ATC ATT GCA ATA GCA GG-3' and 5'-GTT CAA ACT TCT GCT CCT GA-3' for P-gp, which yielded a 167-bp product; 5'AGT GGG AAG TAG ATG AGA TGA AGG-3' and 5'-ATA CAC CTG TCT TGG GAT TTT TGT-3' which yielded a 333-bp product; and 5'-TAT GTC GTG GAG TCT ACT GGT GTC-3' and 5'-GTC ATC ATA CTT GGC AGG TTT CTC-3' for GAPDH, which yielded a 492-bp product. PCR reactions were carried out using 30 cycles of $1 \mathrm{~min}$ denaturation at $94^{\circ} \mathrm{C}, 1 \mathrm{~min}$ annealing at $57^{\circ} \mathrm{C}$ (for GAPDH) or at $55^{\circ} \mathrm{C}$ (for P-gp) and 2 min extension at $72^{\circ} \mathrm{C}$, according to the protocol recommended by Novagen. The PCR products were separated on a $1.7 \%$ agarose gel (Invitrogen) and visualised with ethidium bromide on a Typhoon 9210 (GE Healthcare, USA, formerly Amersham Biosciences).

\section{Detection of P-gp by Western blot}

Whole cell lysates were prepared by homogenisation in RIPA buffer (Pierce Biotechnology, USA). Protein concentrations were determined using the Lowry assay. Proteins in the samples were separated by SDS-PAGE on polyacrylamide gradient gels $(8-16 \%)$. The proteins were then transferred by electroblotting onto nitrocellulose (GE Healthcare, USA, formerly Amersham Biosciences). GAP$\mathrm{DH}$ was detected using an anti-GAPDH antibody (Santa Cruz Biotechnology, USA), P-gp was detected using the C219 anti-P-gp monoclonal antibody (Calbiochem, USA), and $\mathrm{CNX}$ was detected using a rabbit polyclonal anti-CNX antibody (Calbiochem, USA). Secondary anti-mouse and anti-rabbit antibodies, both conjugated with horseradish peroxidase (Calbiochem, USA), were used for detection with the aid of the ECL detection system (GE Healthcare, USA, formerly Amersham Biosciences) and a Kodak Image Station 440 CF (USA). 


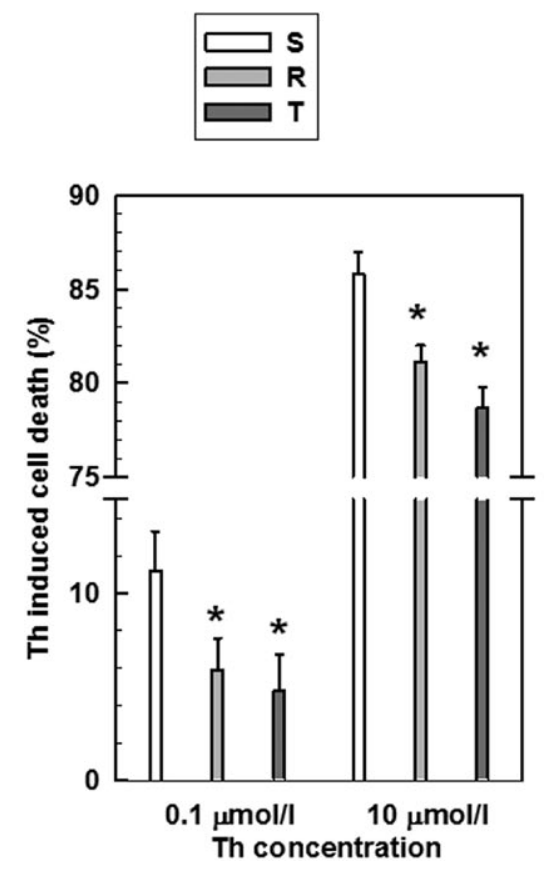

Figure 1. Cell death effect of Th on S, R and T cells. Dead cells stained with propidium iodide (see Material and Methods) were counted by flow cytometry. Data represent means \pm S.E.M. from three independent measurements. ${ }^{*}$ value significantly differs from corresponding value obtained for S cells $(p<0.05)$.

\section{Statistical analysis}

Data were expressed as the mean \pm S.E.M. Statistical significance was assessed using an unpaired Student's $t$-test using SigmaPlot Graphing Software (version 2.01).

\section{Results}

After 8-hour incubation with Th at a concentration $0.1 \mu \mathrm{mol} / \mathrm{l}$, limited death of S, R and T cells occurred; less than $15 \%$ of cells were stainable by propidium iodide (Fig. 1). A higher Th concentration $(10 \mu \mathrm{mol} / \mathrm{l})$ induced massive cell damage, resulting in propidium iodide staining of more than $75 \%$ of cells. S cells were more sensitive to Th than $\mathrm{R}$ and T cells at both Th concentrations, consistent with the Th resistance associated with overexpression of P-gp in MDR cells (Wagner-Souza et al. 2003; Seres et al. 2008).

In contrast to $\mathrm{S}$ cells, which did not contain any P-gp mRNA according to RT-PCR, P-gp mRNA was detectable in both $\mathrm{R}$ and $\mathrm{T}$ cells (Fig. 2). Th at a concentration $0.1 \mu \mathrm{mol} / \mathrm{l}$ did not induce alterations in the levels of P-gp, CNX or GAPDH mRNAs. However, when Th was used at a concentration of $10 \mu \mathrm{mol} / \mathrm{l}$, a decrease in the amounts of CNX, GAPDH (in S, R and T cells) and P-gp (in R and T cells) mRNAs was observed (Fig. 2).
$\begin{array}{lllllll}S & S_{t} & R & R_{t} & T & T_{t}\end{array}$

\section{$0.1 \mu \mathrm{mol} / \mathrm{l}$}
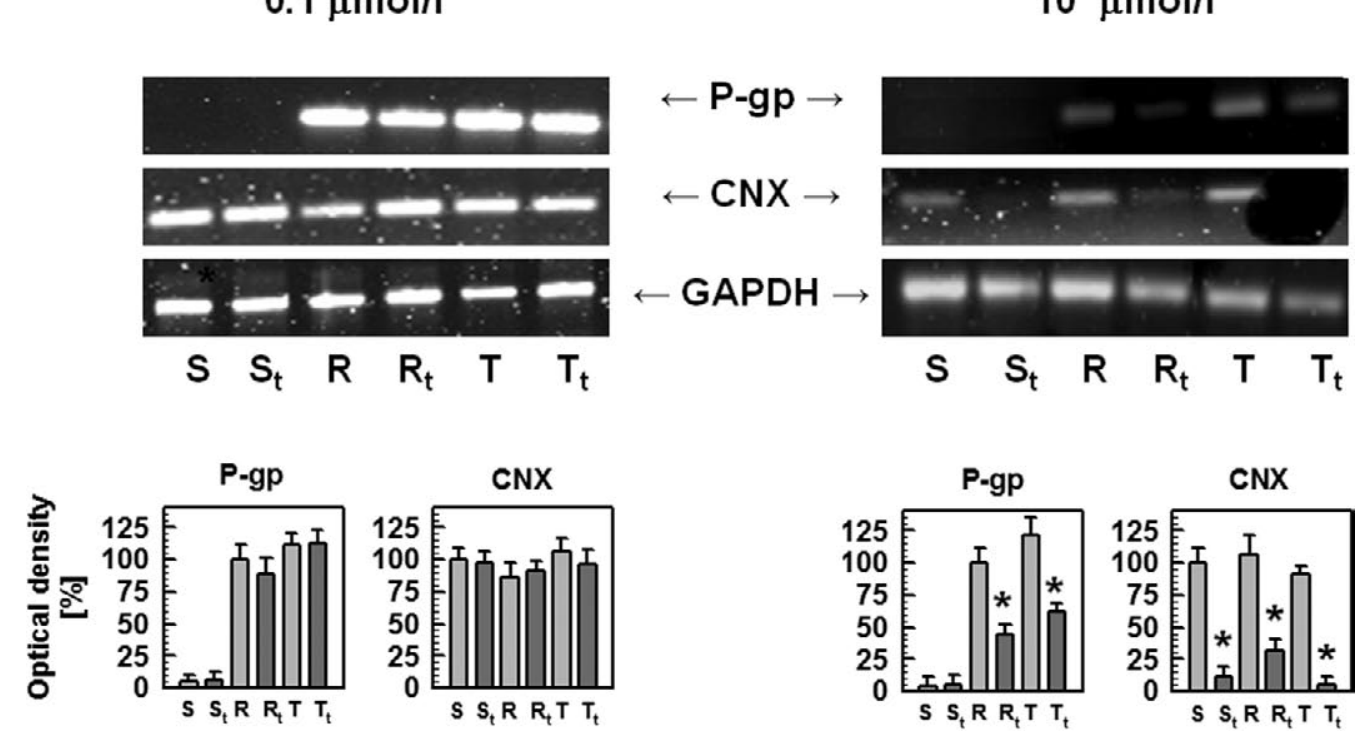

\section{Th concentration}

Figure 2. Effect of Th on the levels of P-gp and CNX mRNAs in S, R and T cells as measured by RT-PCR (see Material and Methods). GAPDH was used as internal standard. The index $t$ indicates cells incubated for 8 hours with Th in cultivation medium. Data represent typical records chosen from three independent experiments that gave similar results (upper panels). All three records were quantified (lower panels) and data were statistically evaluated by unpaired Student's $t$-test. * value in the presence of Th significantly differs from value obtained in the absence of Th on significance level $p<0.02$. 
As expected from the mRNA results, $\mathrm{S}$ cells did not contain P-gp protein according to Western blot (Fig. 3). Th at a concentration of $0.1 \mu \mathrm{mol} / \mathrm{l}$ induced a reduction in the amount of P-gp protein present, particularly for isoforms with higher molecular weights in $\mathrm{R}$ and $\mathrm{T}$ cells (Fig. 3). Similar, though more pronounced results were observed when Th was used at a concentration of $10 \mu \mathrm{mol} / \mathrm{l}$. R and T cells contained lower levels of CNX than $\mathrm{S}$ cells did, which is consistent with the downregulation of CNX in R cells described previously (Seres et al. 2008). While Th at the lower concentration did not alter the levels of CNX in S, R or T cells, the higher Th concentration induced a reduction in the amount of this protein (Fig. 3). S, R and T cells did not differ with respect to the content of GAPDH. However, Th induced a reduction in the amount of this protein present in all cell sublines, an effect that was more pronounced when Th was used at a higher concentration (Fig. 3). Signals of GAPDH were practically diminished in S, R and T cells when $10 \mu \mathrm{mol} / \mathrm{l}$ was applied that indicated on massive cell damage effect that was proved also by propidium iodide staining on Fig. 1.

\section{Discussion}

Both P-gp-expressing cell sublines, $\mathrm{R}$ and $\mathrm{T}$, were less sensitive to Th than P-gp-negative S cells (Fig. 1). This is in agreement with the previously described Th resistance associated with P-gp-mediated MDR (Wagner-Souza et al. 2003; Seres et al. 2008). Th is known to induce intracellular $\mathrm{Ca}^{2+}$-mobilisation associated with the depletion of calcium stores in the endoplasmic reticulum due to inhibition of SERCA (Shoback et al. 1995). However, in P-gp-positive cells, the calcium mobilisation effect of Th was found to absent (Wagner-Souza et al. 2003) - it may be caused, at least partially, by the known The efflux activity of P-gp (Gutheil et al. 1994; Rishi et al. 1998). Nevertheless, the calcium mobilisation effect of Th could not be induced in P-gp-positive cells even when known P-gp inhibitors such as verapamil and cyclosporine A were applied for specific inhibition of P-gp's drug efflux activity (Wagner-Souza et al. 2003). Consistent with this result, we observed only partial restoration of Th sensitivity in $\mathrm{R}$ cells in which P-gp was fully inhibited by verapamil (Seres et al. 2008). Therefore, the Th resistance of P-gp-positive cells could not be fully explained by the Th efflux activity of this transporter.

Th is able to induce decreases in the levels of mRNAs encoding CNX and GAPDH (in S, R and T cells) and P-gp (in $\mathrm{R}$ and $\mathrm{T}$ cells) only when present at a large concentration, i.e., $10 \mu \mathrm{mol} / \mathrm{l}$ (Fig. 2). However, Th at a concentration two orders of magnitude lower was able to downregulate the amount of P-gp, particularly its high molecular weight (about $170 \mathrm{kDa}$ ) fully glycosylated mature isoform. Thus, in our experiments, Th induced defective P-gp processing

\section{Th concentration}

\section{$0.1 \mu \mathrm{mol} / \mathrm{l}$}
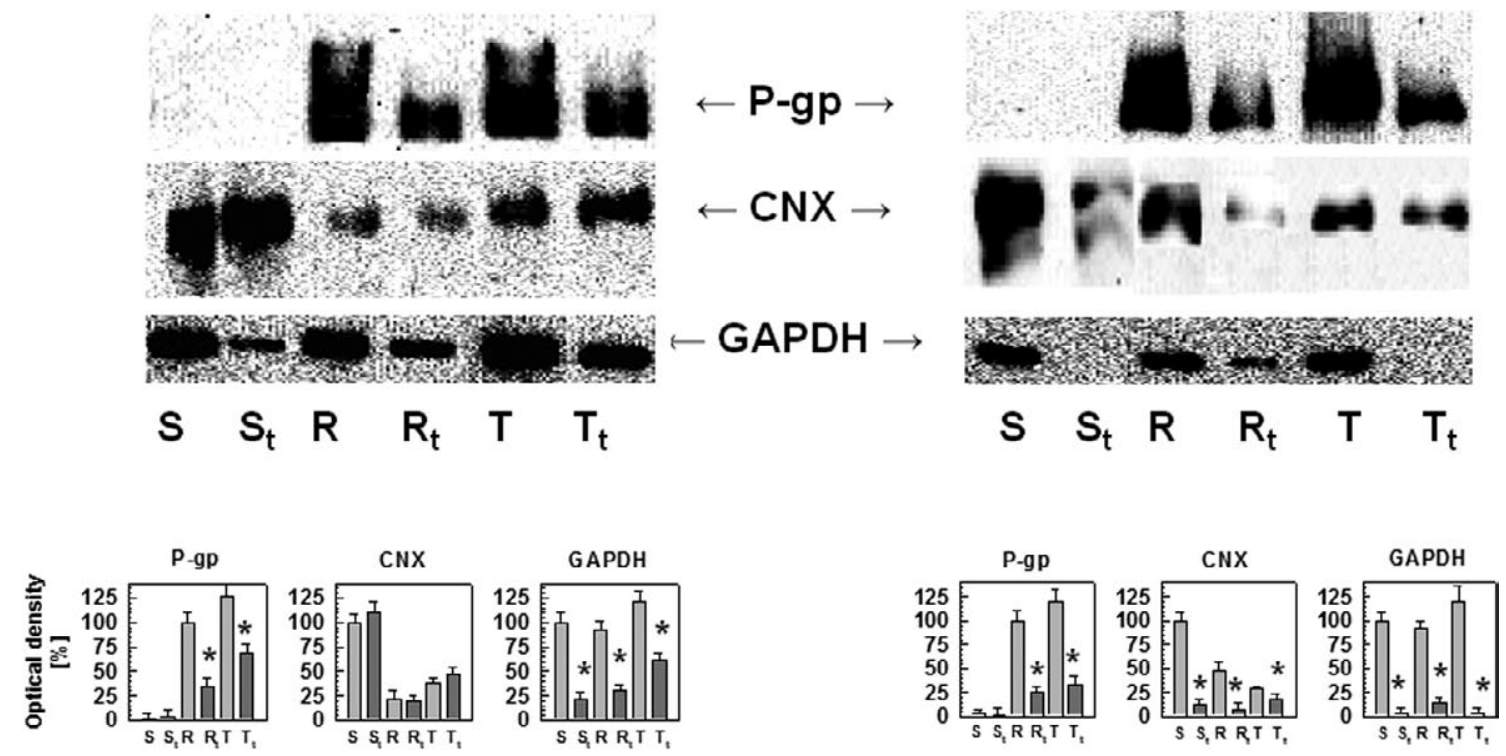

Figure 3. Effect of Th on P-gp, CNX and GAPDH protein contents in S, R and T cells as measured by Western blot (see Material and Methods). Other symbols see in Fig. 2. 
that resulted in an abundance of immature core-glycosylated P-gp with a molecular weight of about $150 \mathrm{kDa}$ (Loo et al. 2004); this isoform had severely reduced or no efflux activity due to inaccurate integration in the plasma membrane. Application of Th at a higher concentration induced more intense effects on P-gp (Fig. 3).

Lower levels of CNX were found in both P-gp expressing cell sublines ( $\mathrm{R}$ and $\mathrm{T}$ ) compared to $\mathrm{S}$ cells (Fig. 3 ). This indicates that the presence of P-gp is directly associated with CNX content regulation independently of how it is expressed. It should be stressed that the downregulation of CNX in $\mathrm{R}$ and $\mathrm{T}$ cells occurred as a result of differences in translation or posttranslational processing because no differences in the amounts of mRNA encoding CNX were found for $\mathrm{R}, \mathrm{T}$ and $\mathrm{S}$ cells (Fig. 2). Decreases in CNX in S, R and T cells could be induced only by application of a high concentration of Th $(10 \mu \mathrm{mol} / \mathrm{l})$.

No significant alterations in the content of GAPDH in S, $\mathrm{R}$ and $\mathrm{T}$ cells were observed. However, application of Th at both applied concentrations induced the downregulation of GAPDH protein levels in all three cell sublines. This result suggests that GAPDH cannot reliably be used as the internal standard for Western blots when the effects of Th are studied.

The Th resistance of P-gp-positive cells represents a complex phenomenon that may involve processes other than the Th efflux activity of P-gp. Th resistance could be linked with several changes in cell phenotype associated with P-gp overexpression, such as differences in calcium homeostasis, which are described elsewhere (Sulova et al. 2005, 2009; Seres et al. 2008). The differences in the CNX levels together with the Th-induced alterations of P-gp glycosylation and P-gp protein levels could be involved in the lower Th sensitivity of $\mathrm{R}$ and $\mathrm{T}$ cells compared with $\mathrm{S}$ cells. Another mechanism could be deduced from the fact that overexpression of P-gp was found to be associated with a lower incidence of apoptosis induced by cisplatin, an anticancer drug that cannot be transported by P-gp (Gibalova et al. 2009). Th has been shown to induce differences in the expression of cell death regulators in DU145 prostatic cancer cells transfected with Bcl-2 (Chaudhary et al. 2001). Thus, the differences in apoptosis regulators associated with the P-gp-mediated MDR phenotype could also be involved in the Th resistance of $\mathrm{R}$ and $\mathrm{T}$ cells.

In conclusion, it can be assumed that the differences in the CNX levels between P-gp-positive and P-gp-negative cells, the Th-induced alteration of the expression and further processing of proteins such as P-gp and GAPDH and the Th efflux activity of P-gp may be involved in the lack of Th sensitivity in P-gp-overexpressing cells.

Acknowledgements. This research was supported in part by the following grants: the Slovak Research and Development Agency
(APVV-0084-07 and VVCE-0064-07) and the Slovak Grant Agency for Science VEGA (2/0123/10 and 2/0155/09).

\section{References}

Baguley B. C. (2010): Multidrug resistance in cancer. Methods Mol. Biol. 596, 1-14; doi:10.1007/978-1-60761-416-6_1

Breier A., Barancik M., Sulova Z., Uhrik B. (2005): P-glycoprotein - implications of metabolism of neoplastic cells and cancer therapy. Curr. Cancer Drug Targets 5, 457-468; doi:10.2174/1568009054863636

Broxterman H. J., Gotink K. J., Verheul H. M. (2009): Understanding the causes of multidrug resistance in cancer: a comparison of doxorubicin and sunitinib. Drug Resist. Updat. 12, 114-126; doi:10.1016/j.drup.2009.07.001

Chaudhary K. S., Abel P. D., Stamp G. W., Lalani E. (2001): Differential expression of cell death regulators in response to thapsigargin and adriamycin in Bcl-2 transfected DU145 prostatic cancer cells. J. Pathol. 193, 522529; doi:10.1002/1096-9896(2000)9999:9999<::AID-PATH821>3.0.CO;2-Y

Gibalova L., Sedlak J., Labudova M., Barancik M., Rehakova A., Breier A., Sulova Z. (2009): Multidrug resistant P-glycoprotein positive L1210/VCR cells are also cross-resistant to cisplatin via a mechanism distinct from P-glycoproteinmediated drug efflux activity. Gen. Physiol. Biophys. 28, 391-403; doi:10.4149/pb_2009_04_391

Gutheil J. C., Hart S. R., Belani C. P., Melera P. W., Hussain A. (1994): Alterations in $\mathrm{Ca}^{2+}$ transport ATPase and P-glycoprotein expression can mediate resistance to thapsigargin. J. Biol. Chem. 269, 7976-7981

Hall M. D., Handley M. D., Gottesman M. M. (2009): Is resistance useless? Multidrug resistance and collateral sensitivity. Trends Pharmacol. Sci. 30, 546-556; doi:10.1016/ j.tips.2009.07.003

Liu R., Zhang Y., Chen Y., Qi J., Ren S., Xushi M. Y., Yang C., Zhu H., Xiong D. (2010): A novel calmodulin antagonist O(4-ethoxyl-butyl)-berbamine overcomes multidrug resistance in drug-resistant MCF-7/ADR breast carcinoma cells. J. Pharm. Sci. 99, 3266-3275

Loo T. W., Bartlett M. C., Clarke D. M. (2004): Thapsigargin or curcumin does not promote maturation of processing mutants of the ABC transporters, CFTR, and P-glycoprotein. Biochem. Biophys. Res. Commun. 325, 580-585; doi:10.1016/j.bbrc.2004.10.070

Loo T. W., Clarke D. M. (1994): Prolonged association of temperature-sensitive mutants of human P-glycoprotein with calnexin during biogenesis. J. Biol. Chem. 269, 28683-28689

Loo T. W., Clarke D. M. (1995): P-glycoprotein. Associations between domains and between domains and molecular chaperones. J. Biol. Chem. 270, 21839-21844

Mestdagh N., Vandewalle B., Hornez L., Henichart J. P. (1994): Comparative study of intracellular calcium and adenosine 3', $5^{c}$-cyclic monophosphate levels in human breast carcinoma cells sensitive or resistant to Adriamycin: contribution to reversion of chemoresistance. 
Biochem. Pharmacol. 48, 709-716; doi:10.1016/00062952(94)90048-5

O'Neill J. P., Velalar C. N., Lee D. I., Zhang B., Nakanishi T., Tang Y., Selaru F., Ross D., Meltzer S. J., Hussain A. (2006): Thapsigargin resistance in human prostate cancer cells. Cancer 107, 649-659; doi:10.1002/cncr.22027

Pastan I., Gottesman M. M., Ueda K., Lovelace E., Rutherford A. V., Willingham M. C. (1988): A retrovirus carrying an MDR1 cDNA confers multidrug resistance and polarized expression of P-glycoprotein in MDCK cells. Proc. Natl. Acad. Sci. U. S. A. 85, 4486-4490; doi:10.1073/ pnas.85.12.4486

Polekova L., Barancik M., Mrazova T., Pirker R., Wallner J., Sulova Z., Breier A. (1992): Adaptation of mouse leukemia cells L1210 to vincristine. Evidence for expression of P-glycoprotein. Neoplasma 39, 73-77

Rishi A. K., Yu M., Tsai-Wu J. J., Belani C. P., Fontana J. A., Baker D. L., Periasamy M., Hussain A. (1998): Gene amplification and transcriptional upregulation of the sarco/endoplasmic reticulum $\mathrm{Ca}^{2+}$ transport ATPase in thapsigarginresistant hamster smooth muscle cells. Nucleic Acids Res. 26, 4529-4537; doi:10.1093/nar/26.19.4529

Rumjanek V. M., Trindade G. S., Wagner-Souza K., de-Oliveira M. C., Marques-Santos L. F., Maia R. C., Capella M. A. (2001): Multidrug resistance in tumour cells: characterization of the multidrug resistant cell line K562-Lucena 1. An. Acad. Bras. Cienc. 73, 57-69; doi:10.1590/S000137652001000100007

Seres M., Polakova E., Krizanova O., Hudecova S., Klymenko S. V., Breier A., Sulova Z. (2008): Overexpression of P-glycoprotein in L1210/VCR cells is associated with changes in several endoplasmic reticulum proteins that may be partially responsible for the lack of thapsigargin sensitivity. Gen. Physiol. Biophys. 27, 211-221

Shoback D., Chen T. H., Pratt S., Lattyak B. (1995): Thapsigargin stimulates intracellular calcium mobilization and inhibits parathyroid hormone release. J. Bone Miner. Res. 10, 743-750; doi:10.1002/jbmr.5650100511

Sulova Z., Ditte P., Kurucova T., Polakova E., Rogozanova K., Gibalova L., Seres M., Skvarkova L., Sedlak J., Pastorek J., Breier A. (2010): The Presence of P-glycoprotein in L1210 Cells Directly Induces Down-Regulation of Cell Surface SaccharideTargets of Concanavalin A. Anticancer Res. (in press)

Sulova Z., Orlicky J., Fiala R., Dovinova I., Uhrik B., Seres M., Gibalova L., Breier A. (2005): Expression of P-glycoprotein in L1210 cells is linked with rise in sensitivity to $\mathrm{Ca}^{2+}$. Biochem. Biophys. Res. Commun. 335, 777-784; doi:10.1016/j.bbrc.2005.07.144

Sulova Z., Seres M., Barancik M., Gibalova L., Uhrik B., Polekova L., Breier A. (2009): Does exists any relation between P-glycoprotein mediated multidrug resistance and intracellular calcium homeostasis. Gen. Physiol. Biophys. (Focused Issue) 28, F89-95

Wagner-Souza K., Echevarria-Lima J., Rodrigues L. A., Reis M., Rumjanek V. M. (2003): Resistance to thapsigargin-induced intracellular calcium mobilization in a multidrug resistant tumour cell line. Mol. Cell. Biochem. 252, 109-116; doi:10.1023/A:1025586225941

Received: September 9, 2010

Final version accepted: October 13, 2010 